\title{
Biogas and Biomass Implementation in Rural Areas
}

\author{
Álvaro A. Sandim ${ }^{1^{*}}$ \\ https://orcid.org/0000-0002-7124-2635 \\ Alexandre G. Batista ${ }^{\text {* }}$ \\ https://orcid.org/0000-0002-7419-4544 \\ Maria Luiza E. Bareta ${ }^{\text {* }}$ \\ https://orcid.org/0000-0001-8448-6260 \\ Roberto C. Betini ${ }^{3^{*}}$ \\ https://orcid.org/0000-0003-1817-6330 \\ Luiz Amilton Pepplow ${ }^{3^{*}}$ \\ https://orcid.org/0000-0001-8124-1778
}

${ }^{1}$ Universidade Tecnológica Federal do Paraná, Electrical Engineering, Curitiba, Brazil; ${ }^{2}$ Universidade Tecnológica Federal do Paraná Electrotechnology Department, Curitiba, Brazil

Received: 2018.11.05; Accepted: 2019.07.26.

* Correspondence: alvaroafonso10@gmail.com; Tel.: +55-41-984635397 (A.A.S); alejjunior@gmail.com; (A.G.B); mlbareta1460@gmail.com; (M.L.E.B); betini@utfpr.edu.br; (R.C.B); luizpepplow@utfpr.edu.br; (L.A.P)

\section{HIGHLIGHTS}

- Show techniques to aid production and lower the cost for some particular type of platting

\begin{abstract}
Advances in energy demand in rural areas cannot be dissociated from agricultural modernization, large estates, mechanization of labor and reduced investment in small production. The use of biogas together with biomass are the most cost-effective ways for the small producer, as it has a high calorific value. In the case of biogas the procedure is performed by combining a compressor and a chiller, allowing the gas enter the reactor and burn together with the air stream. The use of these techniques is an auxiliary way to reduce the cost of the producer to produce a certain crop, besides allowing a participation in the final energy supply, so that the utilities have an alternative to distribute the surplus energy to another region, serving thus a wider range in the rural area.
\end{abstract}

Keywords: Biogas, biomass, rural areas, electricity.

\section{INTRODUCTION}

In the twentieth century, public and private rural electrification programs were implemented in Brazil. These programs expanded access to service provision but failed to serve all households living in rural neighborhoods and interested in providing it. Electricity 
supply to urban neighborhoods presents the least complexities and economic costs when compared to rural neighborhoods. Brazil is among the countries that charge the highest rates for electricity. In the state of Paraná, the tariff charged by Copel in 2018 is 0.53827 reais per $\mathrm{kWh}$, of which $0.1830134 \%$ refers to taxes. With rural activities increasingly automated and productive, it is necessary to increase the demand for electricity and the price of energy weighs on the budget of farmers, mainly irrigation being half of the expenditure on production. The growing interest in the use of clean and renewable energy and the concern about the environmental impacts caused by the emission of pollutants into the atmosphere and the inappropriate disposal of waste has encouraged the development of research around the conscious use of these wastes [2].

\section{MATERIAL AND METHODS}

For study, evaluation and discussion of the problem, a bibliographic study was carried out at CAPES, together with the academic Google. The most significant results come from articles that specifically address the energy potential of biogas and biomass to produce electricity efficiently.

\section{RESULTS}

National energy consumption is getting higher, in the rural sector for example, consumed in $201590.89 \mathrm{GWh}$ being the third largest in the country. Electricity production from biogas by Figure 1. Biogas is obtained through a sewage treatment plant (WWTP). This procedure was performed through a compressor and a cooler, allowing the gas to enter a reactor, where it is combusted. Part of this air is used to heat the water that feeds the boiler. The steam in turn is directed to four turbines, which in parallel provide mechanical power to a generator, which in turn produces electrical power. [3]

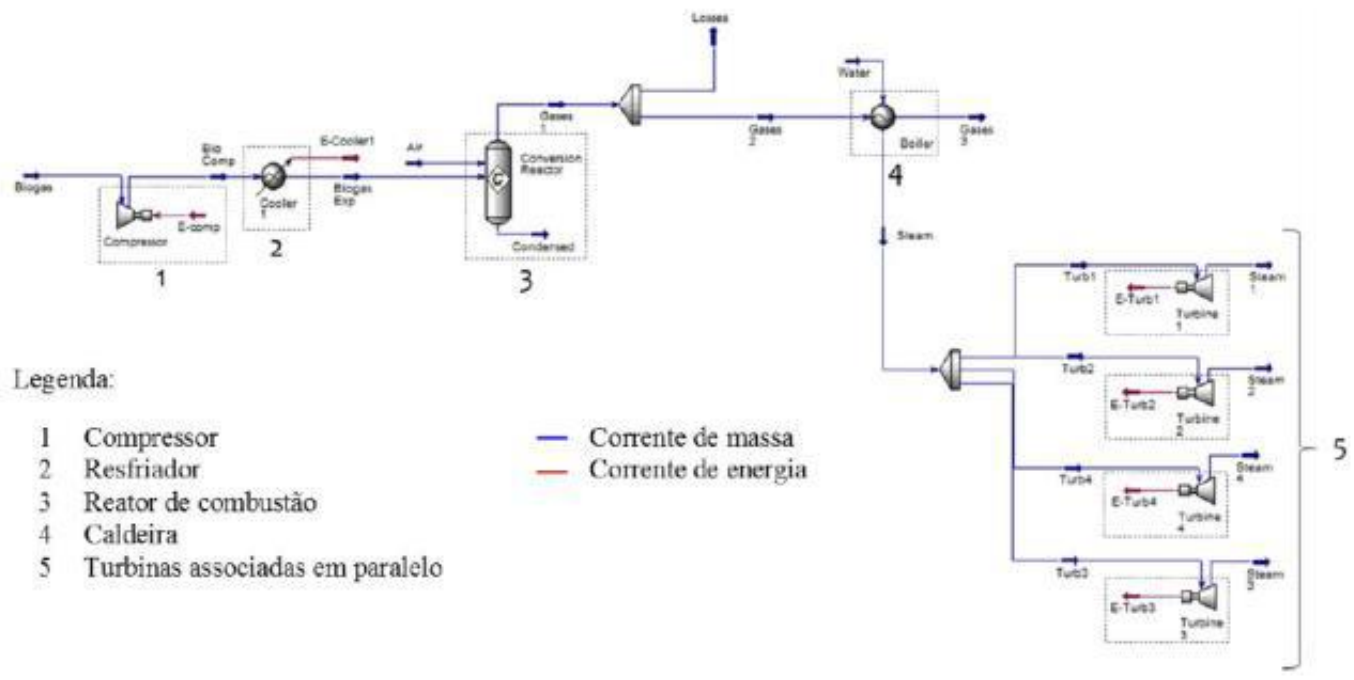

Figure 1. Flow chart

The values in Table 1 show the percentage values of excess production of biogas electricity obtained by the WWTP. Its investment cost is close to $\$ 14$ million and its operating cost just over $\$ 2$ million. [3]

In the city of Colombo-PR, significant data were collected of small and medium producers in rural areas, for biogas production and theoretical electrical potential, from fruit and vegetable residues. Fruit bagasse generating 520 and 93.6 both $\mathrm{m}^{3} / \mathrm{t}$ of fresh mass (MF) and dry mass (MS) respectively. Fruit residues 550 and 74.93 both $\mathrm{m}^{3} / \mathrm{t} \mathrm{MF}$ and MS. Vegetable waste 450 and 72 both $\mathrm{m}^{3} / \mathrm{t}$ MF and MS. [1] 
Table 1: Energy percentage of excess prodution

\begin{tabular}{ccc}
\hline & Value & $\begin{array}{c}\text { Energy } \\
\text { percentage(\%) }\end{array}$ \\
\hline $\begin{array}{c}\text { Total useful } \\
\text { energy } \\
\left(\text { MJ.day }{ }^{-1}\right)\end{array}$ & 78.168 & - \\
$\begin{array}{c}\text { Total useful } \\
\text { energy } \\
(\text { MJ.day }\end{array}$ ) \\
$\begin{array}{c}\text { Total useful } \\
\text { energy } \\
\left(\text { MJ.day }^{-1}\right)\end{array}$ & 5.709 & 7 \\
\hline
\end{tabular}

\section{DISCUSSION}

The studied results show a big difference in the production of electric energy by biogas. Being the first compared for a large production and high investment to be realized. Both are alternatives to improve day-to-day waste to reduce environmental impacts.

They also show a promising future for the use of biogas, and it is possible to obtain significant amounts of electricity to use or return to the grid the values of investment and operation cost.

\section{CONCLUSION}

The growing interest in the use of renewable energy and concern with environmental impacts, promotes the improvement of reuse of surplus produced to assist in indirect production. However, with the investment and operation cost values, they do not generate energy production with a competitive value compared to the national one, and subsidies are necessary to facilitate their immersion in the market. On the other hand, the generation of electricity from horticultural residues is viable for small and medium producers, being possible to harness this energy in other activities.

\section{REFERENCES}

1. Christo, $L$ et al. Potencial de produção de biogas e energia elétrica a partir de resíduos de hortifruticultura em Colombo-pr. Disponível em: <https://webcache.googleusercontent.com/search?q=cache:LAoEiJHQpygJ:https://revistas.ufpr.br/b iofix/article/download/56058/34916+\&cd=1\&hl=pt-BR\&ct=clnk\&gl=br\&client=firefox-b-ab> Acesso em: set, 2018.

2. Jeronymo, Alexandre Cosme José; GUERRA, Sinclair Mallet-Guy. Caracterizando a evolução da eletrificação rural brasileira. Redes (Santa Cruz do Sul. Online), Santa Cruz do Sul, v. 23, n. 1, p. 133-156, jan. 2018. ISSN 1982-6745. Disponível em: <https://online.unisc.br/seer/index.php/redes/article/view/9816>. Acesso em: 16 out. 2019. doi:https://doi.org/10.17058/redes.v23i1.9816.Acesso em: set, 2018

3. Gomes, G. V.; Suda, S. J.; Rosa, A. P.; Rodrigues, F. A. Estudo da Produção de Energia Elétrica a partir de biogas em e sem purificação de estação de tratamento de esgosto. Disponível em: $<$ https://www.researchgate.net/publication/321787228_ESTUDO_DA_PRODUCAO_DE_ENERGIA ELETRICA_A_PARTIR_DE_BIOGAS_COM_E_SEM_PURIFICACAOODE_ESTACAO_DE_TRAT AMENTO_DE_ESGOTO> Acesso em: set, 2018 